\title{
Application of Natural Antimicrobial Additives and Protective Culture to Control Aerobic Spore Forming Bacteria in Low Salt Soft Cheese
}

\author{
Eman K. Abo Shaala ${ }^{1 *}$, Sameh A. Awad ${ }^{2}$, and Ashraf M. Nazem ${ }^{1}$ \\ ${ }^{I}$ Department of Food Hygiene, Faculty of Veterinary medicine, Alexandria University, Egypt \\ ${ }^{2}$ Department of Dairy Science and Technology, Faculty of Agriculture, Alexandria University, Egypt \\ *Corresponding author's Email: keman718@gmail.com; (DORCiD: 0000-0003-4573-2056
}

\begin{abstract}
There is an increasing interest in the application of natural antimicrobials instead of chemical ones to enhance the microbiological quality of dairy products. The objective of this study was to assess the effect of some natural antimicrobial additives and protective culture for reducing the usage of chemical preservatives, shelf-life extension, retarding microbial spoilage in low-salt soft cheese. The antimicrobial agents (protective culture, nisin, lysozyme, and natamycin) were studied on the activity of 28 isolates of spore-forming bacteria. Inhibitory effect of different natural antimicrobial additives as protective culture (Lactobacillus rhamnosus, $\left.40 \mathrm{mg} \mathrm{kg}^{-1}\right)$, nisin $\left(25 \mathrm{mg} \mathrm{kg}^{-1}\right)$, lysozyme $\left(100 \mathrm{mg} \mathrm{kg}^{-1}\right)$, combination of nisin and lysozyme $\left(25 \mathrm{mg} \mathrm{kg}^{-1} / 100 \mathrm{mg} \mathrm{kg}^{-1}\right)$, and combination of protective culture and natamycin $\left(40 \mathrm{mg} \mathrm{kg}^{-1} / 25 \mathrm{mg} \mathrm{kg}^{-1}\right)$ were studied on the growth of aerobic spore-forming bacteria in low-salt soft cheese during the storage period (30 days) at $4 \pm 1^{\circ} \mathrm{C}$. The results revealed that the addition of different natural antibacterial additives with various concentrations had a significant effect on aerobic spore-forming bacteria, compared to other treatments and control. The growth pattern of aerobic spore-forming bacteria gradually decreased in all treatments along the storage period with variable reduction percentages in comparison with control cheese which was in continuous increment. The application of a combination of nisin and lysozyme had the most significant reduction of aerobic spore-forming bacteria, compared to control and other treatments.
\end{abstract}

Keywords: Aerobic spore-forming bacteria, Lysozyme, Nisin, Natamycin, Protective culture

\section{INTRODUCTION}

Soft cheese is one of the oldest dairy products with the best nutritive value and health keeping function. It is popular in many countries worldwide with palatable taste and various flavor (Awad et al., 2012). Cheese consumption has greatly increased during the past decade in the world (Elsamani et al., 2014). Considering the common consumption of cheeses, there is a growing concern regarding its safety and microbiological quality (Al-Gamal et al., 2019). Soft cheese manufacturing procedures include standardization and in many cases pasteurization of milk, acidification mainly through indigenous production of lactic acid by specific bacteria, coagulation of milk by rennet, dehydration of the curd by transforming coagulum into specific characteristic shapes; the resultant cheese could be consumed fresh or matured (After ripening of the curd, Fox et al., 2017). Salt is a vital component as it affects many aspects of cheese including shelf-life, activity of enzymes, flavor, casein hydration, and microbial proliferation during ripening. Salt is applied during cheese making for several purposes including acquiring the desirable flavor and texture, preservative action, and as a taste enhancer. Many consumers not prefer cheese with elevated salt percentage, mainly due to health risks such as hypertension, cardiovascular disease (CVD), stroke and heart attacks (Bae et al., 2017).

Aerobic spore-forming bacteria mainly Bacillus are of great importance in the dairy industry as the spores of these bacteria in raw milk can survive during pasteurization as well as other processing treatments and finally existed into final products (Coorevits et al., 2008). They are considered one of the most important genera encountered in the spoilage of milk and dairy derivatives. In addition, Bacillus is also involved in the formation of biofilms on stainless steel surface lines of dairy plant equipment (Lopez-Brea et al., 2018). The presence of Bacillus enzymes such as proteases in milk may decrease yield and shorten the required time for coagulation during cheese manufacturing due to the elevated concentration of amino acids that enhance the growth of starter culture quickly (Kumari and Sarkar, 2016). Furthermore, their germination leads to food spoilage as they threaten dairy products manufacturing due to high economic losses, impairment of equipment, and reputational damage of food companies or pathogenic cases resulted from food borne illness (Egan et al., 2016). Some Bacillus species cause two types of foodborne diseases, an emetic (vomiting) intoxication and diarrheal infection. The former has resulted from the ingestion of a preformed toxin in food, and the latter originates from eating bacterial cells/spores that release enterotoxins in the small intestine (Budka et al., 2005). 
Contamination of milk and dairy derivatives with spore-forming bacteria involves two routes of the entrance, namely the raw milk route and the post pasteurization route. Raw milk in the farm tank is contaminated through cattle's teats and inefficiently cleaned milking facilities contaminated by soil, faeces and bedding material. Soil is the primary and direct contamination origin of spore-forming bacteria into foods, since it is a major source of these microorganisms. On the other hand, the post pasteurization contamination of milk with spores is associated with the dairy industry or to the biofilms of spore-forming bacteria growing in processing lines that can finally be widely spread by release into the system of milk production (Heyndrickx, 2011). Improperly cleaned facilities and poor handling within the dairy plant is also considered as main sources and shedders of the contamination of spore formers at dairy processing equipment (Faille et al., 2014).

There is an increasing interest in the application of bio-preservation methods that utilize natural antimicrobial compounds such as nisin, lysozyme and protective culture (Sudagidan and Yemenicioğlu, 2012). Nisin has been evidenced as (Generally Regarded as Safe) by the US Food and Drug Administration (FDA) since 1988 as it has been long applied in food protection (E234) without being associated with health problems (Gharsallaoui et al., 2016). Application of nisin alone, or combined with other treatments as lysozyme, could provide a desirable advance for the microbiological safety and keeping of sensory criteria in milk and dairy products (Sobrino-López and Martín-Belloso, 2008). The functional characteristics of lysozyme as a natural antiviral and antibacterial substance have been implicated in industrial applications, especially in the food, pharmaceutical and medical industries (Arabski et al., 2015). Most food fermentation processes include mixed cultures in which various microbial species interact with each other. These interactions may have a neutral, positive or negative impact on the activity of the strains performing the fermentation (Arioli et al., 2016). Protective cultures have strong antagonistic activity against food-spoilage and pathogenic aerobic spore-forming bacteria as a result of the production of bacteriocins, inhibitory enzymes, organic acids and hydrogen peroxide (Ibrahim and Awad, 2018). Consumers have an increasing knowledge of health risks caused by the usage of chemical preservatives. Therefore, there is an increasing requirement in the dairy industry to prolong product shelf-life and inhibit spoilage by natural preservatives and/or new methods of conservation (Silva et al., 2018). Therefore, this research aimed to study the application of some natural antimicrobial additives (Nisin, lysozyme, protective culture and natamycin) to enhance the quality, shelf-life and safety of low-salt soft cheese.

\section{MATERIALS AND METHODS}

\section{Materials}

The employed materials in the current study included fresh buffalo milk obtained from a small dairy farm at Abis, Alexandria governorate. Microbial rennet: Fromase, France, Nisin: manufactured in the Netherlands by Siveele B.V, imported by AWA Food Solution. $4^{\text {th }}$ Industrial area, New Borg Al Arab City. Alexandria, found in the market in form of powder with commercial name Nisaplin ${ }^{\circledR}$ and has the EU food additive number E234. Natamycin: from Spain, Imported by AWA Food Solution. $4^{\text {th }}$ Industrial area, New Borg Al Arab City. Alexandria. Lysozyme: Lysozyme from chicken egg white was from Merck, Germany. Protective culture (Lyofast LRB), SACCO Co, Italy. It consists of a selected strain of lactobacillus rhamnosus (Used in dairy derivatives as non-starter lactic acid bacterial culture, which provides a slight acidity and smell from slow fermentation). Spore forming isolates included 28 strains isolated from commercial low-salt soft cheese collected from Egyptian markets. These isolates were purified and classified as aerobic spore-forming bacteria (study under publication).

\section{Methods}

\section{Low-salt soft cheese manufacture}

Low-salt soft cheese was made according to the method adopted by Fahmi and Sharara (1950). Fresh buffalo`s milk was used for manufacturing six treatments of low-salt soft white cheese. Raw milk was pasteurized at $63^{\circ} \mathrm{C}$ for 30 min, cooled to $37{ }^{\circ} \mathrm{C}$, then calcium chloride and sodium chloride was added in $0.02 \%$ and $3 \%$ (w/v). Cheese milk was divided into six portions, then, the additives for each treatment were added individually. The commercial rennet was added to the milk and incubated at $37^{\circ} \mathrm{C}$ for coagulation within $90 \mathrm{~min}$. The treatments of low-salt soft white cheeses using pasteurized milk were as following: pasteurized milk with no additives as a control (Treatment 1), pasteurized milk with adding protective culture $(40 \mathrm{mg} / \mathrm{kg}$, Treatment 2$)$, pasteurized milk with adding lysozyme (100 mg/kg, Treatment 3 ), pasteurized milk with adding nisin $(25 \mathrm{mg} / \mathrm{kg}$, Treatment 4), pasteurized milk with adding nisin and lysozyme (25 $\mathrm{mg} / \mathrm{kg}+100 \mathrm{mg} / \mathrm{kg}$, Treatment 5), pasteurized milk with adding protective culture and natamycin $(40 \mathrm{mg} / \mathrm{kg}+25 \mathrm{mg} / \mathrm{kg}$, Treatment 6). In treatments of protective culture (T2 and T6), the protective culture (lyofast LRB) $200 \mathrm{mg}$ were added to $5 \mathrm{~kg}$ milk according to the recommendation of suppliers followed by incubation at $37{ }^{\circ} \mathrm{C}$ for 1 hour then adding $\mathrm{NaCl}(3$ $\%), \mathrm{CaCl}_{2}(0.02 \%)$ and finally the addition of rennet $(0.002 \%(\mathrm{w} / \mathrm{v}))$ to coagulate milk within 90 min using the same procedure as in other treatments. 


\section{Microbiological evaluation of laboratory manufactured low-salt soft cheese}

Using aseptic technique, 5 grams of low salt laboratory manufactured soft cheese were transferred by sterile spatula to a sterile polyethylene bag then adding $45 \mathrm{ml}$ sterilized sodium citrate $2 \%$, bags were placed in a stomacher for shaking at $160 \mathrm{rpm}$ for $5 \mathrm{~min}$, then serial dilutions using sterilized sodium citrate 2\% were performed (Wehr and Frank, 2012).

\section{Enumeration of aerobic spore-forming bacteria}

All previous prepared serial dilutions were heated in a water bath at $80{ }^{\circ} \mathrm{C}$ for 10 min then cooled suddenly to the $30^{\circ} \mathrm{C}$ before transferring one $\mathrm{ml}$ aliquots into sterilized Petri dishes containing nutrient agar. The duplicate plates were incubated at $32{ }^{\circ} \mathrm{C}$ for 48 hours. Mesophilic aerobic spore-forming bacteria were enumerated on nutrient agar after incubation (Wehr and Frank, 2012).

\section{Isolation of aerobic spore-forming bacteria}

Colonies suspected as Bacillus species based on colony morphology, spread with usual features e.g slimy, crusty, dry, embedded or forming skin-like pellicles, were sub-cultured in nutrient broth at $32^{\circ} \mathrm{C}$ for 48 hours, then purified on non-selective medium nutrient agar plates for another 48 hours at $32^{\circ} \mathrm{C}$. The isolates were inoculated into the nutrient broth and incubated at $32^{\circ} \mathrm{C}$ for 48 hours and then stored in Eppendorf tubes containing nutrient broth with 15-20\% glycerol at $-20^{\circ} \mathrm{C}$ for further examinations (Wehr and Frank, 2012).

\section{Studying the antibacterial activity of natural additives against isolated spore-forming bacteria}

Natural antimicrobial agents such as nisin, lysozyme, protective culture and natamycin were evaluated to inhibit the growth of all isolates of spore-forming bacteria. Each of the tested isolated strains was inoculated in nutrient agar medium in Petri plates, After solidification of agar, four-wells in each plate were performed, each natural antibacterial additives such as nisin, lysozyme, protective culture and natamycin with identified concentration and quantity as follow $100 \mu \mathrm{l}$ of nisin (25\% concentration), $100 \mu \mathrm{l}$ of natamycin (concentration $25 \%$ ), $100 \mu \mathrm{l}$ of protective culture (concentration $0.04 \%)$ lysozyme $100 \mu \mathrm{l}\left(0.1 \%\right.$ concentration) was placed in the wells. The plates were incubated at $37^{\circ} \mathrm{C}$ for 24 hours and then recording of inhibition zone to determine their effectiveness against isolated aerobic spore-forming bacteria. This was carried out according to Performance Standards for Antimicrobial Susceptibility Testing (CLSI, 2018).

\section{Statistical analysis}

Statistical analysis of the data was performed using ANOVA, F-test, and LSD procedures available within the SAS software package (version 9.13 2008). Means with a significant difference were compared by Duncan's multiple range tests according to Steel and Torrie (1980). All physicochemical and microbiological analyses were performed in duplicate.

\section{RESULTS}

As can be seen in Table (1), the reduction percentage of aerobic spore-forming bacteria in laboratory manufactured lowsalt soft cheese treated with different concentrations of natural antimicrobial additives during the storage period (30 days) at $4 \pm 1^{\circ} \mathrm{C}$. The addition of protective culture $(40 \mathrm{mg} / \mathrm{kg})$ reduced aerobic spore- forming bacteria on first day of analysis by $7.41 \%$, reduction percentage increased on the day 14 of storage to reach $83.10 \%$ then the reduction percentage was at a high rate $(90.94 \%)$ on day 30 of storage. Aerobic spore- forming bacteria in cheese treated with lysozyme $(100 \mathrm{mg} / \mathrm{kg})$ reduced by $33.68 \%$ on first day of manufacturing then reached $97.82 \%$ on the day 30 of storage. Losing percent of aerobic spore-forming bacteria in cheese treated with nisin $(25 \mathrm{mg} / \mathrm{kg}$ ) was $31.60 \%, 90.32 \%, 96.54 \%$ on days 1, 14 and 30 of storage, respectively. Reduction percentage of aerobic spore-forming bacteria in cheese treated with combined nisin and lysozyme $(25 \mathrm{mg} / \mathrm{kg}$ and $100 \mathrm{mg} / \mathrm{kg})$ was at the highest rate among other additives on first day of analysis as was $51.50 \%$ then increased to $93.97 \%$ on the day 14 of storage then reduction percentage elevated sharply on the day 30 of storage to reach $97.82 \%$. The addition of a combination of protective culture plus natamycin $(40 \mathrm{mg} / \mathrm{kg}$ and $25 \mathrm{mg} / \mathrm{kg}$ ) to cheese led to a reduction percentage of $21.18 \%$ at the first analysis then elevated to $92.78 \%$ at the second analysis then finally increased greatly on the day 30 of storage to reach $93.08 \%$ (Figure 1). Results recorded in Table 2 showed that the mean value of inhibition zone $(\mathrm{mm})$ of nisin against isolated spore-forming bacteria was $25.30 \pm$ $11.9 \mathrm{~mm}$, while the mean value of inhibition zone diameter of lysozyme against isolated spore-forming bacteria was $32.90 \pm 19.30$. The mean value of inhibition zone diameter of protective culture against isolated aerobic spore-forming bacteria was $26.10 \pm 10.20$. Natamycin had no inhibitory effect against spore-forming bacteria. 


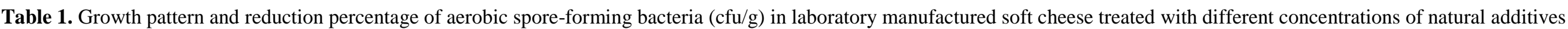
during storage period (30 days) at $4 \pm 1{ }^{\circ} \mathrm{C}$.

\begin{tabular}{|c|c|c|c|c|c|c|c|c|c|c|c|c|}
\hline \multirow{3}{*}{ Period time (day) } & \multirow{2}{*}{\multicolumn{2}{|c|}{ Control }} & \multicolumn{10}{|c|}{ Natural additives } \\
\hline & & & \multicolumn{2}{|c|}{$\begin{array}{l}\text { Protective culture } \\
\quad\left(40 \mathrm{mg} \mathrm{kg}^{-1}\right)\end{array}$} & \multicolumn{2}{|c|}{$\begin{array}{c}\text { Lysozyme } \\
\left(100 \mathrm{mg} \mathrm{kg}^{-1}\right)\end{array}$} & \multicolumn{2}{|c|}{$\begin{array}{c}\text { Nisin } \\
\left(25 \mathrm{mg} \mathrm{kg}^{-1}\right)\end{array}$} & \multicolumn{2}{|c|}{$\begin{array}{c}\text { Nisin }\left(25 \mathrm{mg} \mathrm{kg}^{-1}\right)+ \\
\text { lysozyme }\left(100 \mathrm{~g} \mathrm{~kg}^{-1}\right)\end{array}$} & \multicolumn{2}{|c|}{$\begin{array}{c}\text { Protective culture } \\
\left(40 \mathrm{mg} \mathrm{kg}^{-1}\right)+\text { Natamycin }^{-1} \\
\left(25 \mathrm{mg} \mathrm{kg}^{-1}\right)\end{array}$} \\
\hline & Mean \pm SD & $\mathrm{R} \%$ & Mean \pm SD & $\mathrm{R} \%$ & Mean \pm SD & $\mathrm{R} \%$ & Mean \pm SD & $\mathrm{R} \%$ & Mean \pm SD & $\mathrm{R} \%$ & Mean \pm SD & $\mathrm{R} \%$ \\
\hline 1 & $864 \pm 0.71^{\mathrm{a}}$ & 0 & $800 \pm 0.71^{\mathrm{b}}$ & 7.41 & $573 \pm 0.71^{\mathrm{e}}$ & 33.68 & $591 \pm 0.71^{\mathrm{d}}$ & 31.60 & $419 \pm 0.71^{\mathrm{f}}$ & 51.50 & $681 \pm 1.41^{\mathrm{c}}$ & 21.18 \\
\hline 14 & $1509 \pm 0.71^{\mathrm{a}}$ & 0 & $255 \pm 0.71^{\mathrm{b}}$ & 83.10 & $119 \pm 0.71^{\mathrm{e}}$ & 92.11 & $146 \pm 0.71^{\mathrm{d}}$ & 90.32 & $91 \pm 0.71^{\mathrm{f}}$ & 93.97 & $109 \pm 0.71^{\mathrm{c}}$ & 92.78 \\
\hline 30 & $2109 \pm 0.71^{\mathrm{a}}$ & 0 & $191 \pm 0.71^{\mathrm{b}}$ & 90.94 & $46 \pm 0.71^{\mathrm{e}}$ & 97.82 & $73 \pm 0.71^{d}$ & 96.54 & $46 \pm 0.71^{f}$ & 97.82 & $146 \pm 0.71^{c}$ & 93.08 \\
\hline
\end{tabular}

$\mathrm{SD}=$ Standard deviation, $\mathrm{R} \%=$ Reduction percentage, $*$ Means carrying a different superscript small letter on the same row are significantly different $(\mathrm{P} \leq 0.05)$.

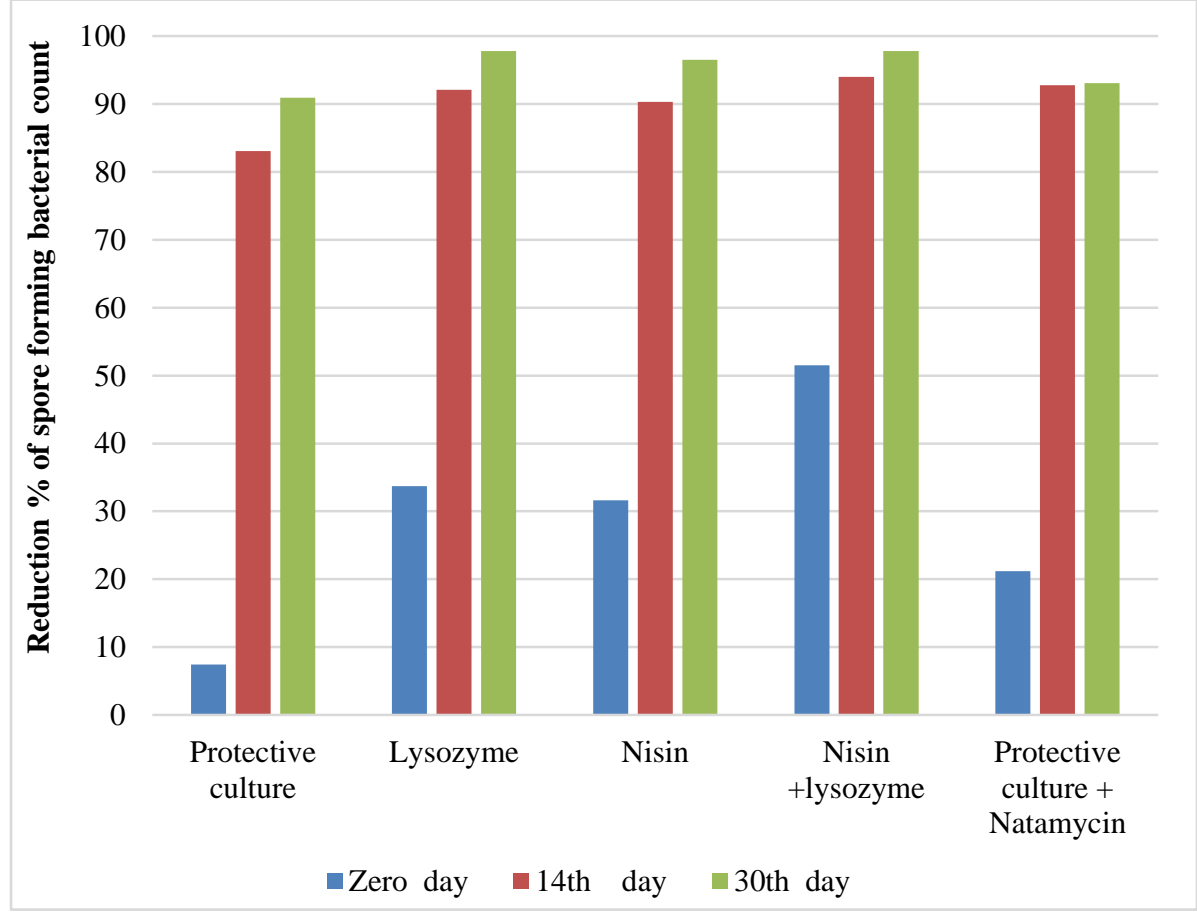

Figure 1. Effect of protective culture and some Natural antimicrobial additives on the reduction count of spore- forming bacteria in low-salt soft cheese
Table 2. Antibacterial activity of natural additives against isolated aerobic spore-forming bacteria (inhibition zone $\mathrm{mm}$ )

\begin{tabular}{lcccc}
$\begin{array}{l}\text { Number of } \\
\text { Tested Isolates }\end{array}$ & Nisin & Lysozyme & Protective culture & Natamycin \\
\hline & & \multicolumn{2}{c}{ Inhibition Zone $(\mathbf{m m})$} \\
\hline \\
\hline Mean \pm SD & Mean \pm SD & Mean \pm SD & Mean \pm SD \\
\hline 28 & $25.30 \pm 11.9$ & $32.90 \pm 19.30$ & $26.10 \pm 10.20$ & Not Detected \\
\hline
\end{tabular}

$\mathrm{SD}=$ Standard deviation 
Reduction percentage of aerobic spore forming bacteria in laboratory manufactured soft cheese treated with different concentrations of natural additives during storage period ( 30 days) at $4 \pm 1^{\circ} \mathrm{C}$

Natural antimicrobial additives are a magic substitute for chemical preservatives for the maintenance of dairy product safety and microbiological quality (Lopes et al., 2019). Spore-forming bacteria cause significant economic losses and health problems in the dairy industries (Coorevits et al., 2010). They are commonly distributed in the environment and are associated with varieties of dairy products. Their existence in foods constitutes great problematic issues because the formation of their spores enables them to be resistant to thermal processing, freezing, chemical agents, and other difficult conditions that the food faces during processing operations. However, the vegetative cells are destroyed by these factors, traditionally these microorganisms have been related to the spoilage of dairy products; recently they have been associated with potential food poisoning cases (Rodriguez-Lozano et al., 2010). Multiplication of aerobic spore formers in raw milk liberates extracellular lipase enzyme, which is attached to milk fat globules and concentrated in the manufactured cheese in the course of making, the enzyme adversely causes bitter flavor by hydrolysis of fat into fatty acids and glycerides. This enzyme could be inactivated by pasteurization but thermal treatment could not destroy it (Beresford et al., 1998). The reduction percentage of aerobic spore-forming bacteria exerted by protective culture LAB strains reached $90.94 \%$ at the last analysis since some types of lactobacillus (such as lactobacillus rhamnosus) can produce antimicrobial factors such as organic acids (lactic acid and acetic acid), ethanol, hydrogen peroxide, diacetyl, acetoin, acetaldehyde, carbon dioxide and bacteriocins that could develop in various ways a potent inhibitory action against many microorganisms involving pathogenic and spoilage ones of aerobic spore formers (Al-Gamal et al., 2019). Lysozyme hydrolyzes $1,4-\beta$-bond between $\mathrm{N}$-acetylmuramic acid, and $\mathrm{N}$-acetylglucosamine were found in the peptidoglycan leading to the suppression of growth, multiplication and prevalence of aerobic spore-forming bacteria which finally decreased from $573 \pm 0.71$ on the first day of analysis to $46 \pm 0.71$ on the day 30 of storage (Abdou et al., 2013). With the final reduction percentage of $97.82 \%$, lysozyme showed strong bactericidal action against aerobic spore formers mainly Bacillus species (Abdou et al., 2007). Cheese is considered one of the well-known food applications of lysozyme where it governs spoilage microorganism's growth. Application of lysozyme in soft cheese can result in extending shelf-life and prevention of total bacteria including spore formers, yeast and mold (Doosh and Abdul-Rahman, 2014). Lysozyme content in cheese usually ranged between 50 and $350 \mathrm{mg} / \mathrm{kg}$ of cheese weight (Ávila et al., 2014). Nisin exerts its effect by attacking the cell wall so destroy the target microorganisms (Gharsallaoui et al., 2016). Loss of potassium ion of the bacterial cell, depolarization of the cytoplasmic membrane, depression of respiration, and partial efflux of cellular ATP are the mechanisms of action of nisin (Omardien et al., 2016). Nisin exhibited its inhibitory action after the initiation of germination, where nisin attached to lipid II in the spore after outgrowth and inhibited it from becoming metabolically active by interfering with the formation of membrane potential and oxidative metabolism. Germination initiation was required for this lipid II binding to happen as nisin cannot bind to the dormant spore due to the absence of lipid II on the external of the spore (Gut et al., 2011). The reduction percentage of aerobic spore formers in cheese treated with nisin elevated from $31.60 \%$ at first analysis to $96.54 \%$ on the day 30 of storage. It has been noticed that the action of nisin is elevated when it is in combination with other additives such as lysozyme (Chung and Hancock, 2000). Application of lysozyme and nisin in soft cheese can lead to the extension of shelf-life and prevention of spoilage (Zottola et al., 1994; Doosh and Abdul-Rahman, 2014). Application of combination between nisin and lysozyme has the most significant reduction of spore-forming microorganisms in comparison with control and other treatments, which decreased from $419 \pm 0.71$ on the first day of analysis to $46 \pm 0.71$ on the day 30 of storage. These findings are in line with those reported by López-Pedemonte et al. (2003), Meruvu et al. (2011) and Ávila et al. (2014) who found that nisin and lysozyme combination were the most effective against gram-positive aerobic spore formers such as Bacillus species.

\section{Studying the antibacterial activity of natural additives against isolated spore-forming bacteria}

The mean value of inhibition zone of nisin against isolated spore-forming bacteria was $25.30 \pm 11.9 \mathrm{~mm}$, which was in the same range as those reported by Pirttijärvi et al. (2001) showing that the application of diluted nisin led to an inhibition zone around 3-30 mm against many species of aerobic spore-forming bacteria. Nisin effectively suppresses the counts of aerobic spore-forming bacteria during 24hour incubation in the lab that is sufficient for industrial application. Additionally, our results are higher than the data mentioned by Morsy et al. (2018) reporting that the inhibition zone of nisin against aerobic spore-forming bacteria was $15 \pm 1.32$. Nisin has been used to prevent spore out growth in many types of cheese especially soft cheese also is useful for inhibiting different types of aerobic spore formers (Komitopoulou et al., 1999). The mean value of inhibition zone diameter of lysozyme against isolated spore-forming bacteria was $32.90 \pm 19.30$ that is higher than results obtained by Morsy et al. (2018) who illustrated that the inhibition zone of lysozyme against aerobic spore formers was $14 \pm 1.11$ and lower than the data presented by Ramanauskiene et al. (2009) who found that lysozyme produced a clear zone of inhibition of $38.52 \pm 0.17$ against aerobic spore formers. The mean 
value of the inhibition zone diameter of the protective culture against isolated aerobic spore- forming bacteria was 26.10 \pm 10.20. These results are higher than data reported by Tharmaraj and Shah (2009) who found that lactobacillus rhamnosus produced an inhibition zone of 0-15 mm against aerobic spore-forming bacteria and also higher than data mentioned by Coman et al. (2014) who illustrated that lactobacillus rhamnosus showed inhibition zone of $11.80 \pm 0.71$ against aerobic spore-forming bacteria. The findings did not support the study conducted with Hawaz (2014) who reviewed that the addition of protective culture (lactobacillus rhamnosus) produced no inhibition zone against aerobic spore-forming bacteria. Spore-forming bacteria were reduced by the protective culture (lactobacillus rhamnosus) organisms to a greater extent than the non-spore formers, the inhibitory action of protective culture was strongest against aerobic spore-formers (Tharmaraj and Shah, 2009). Natamycin had no inhibitory effect against spore-forming bacteria. It destroys yeasts by specifically attaching to ergosterol and without permeabilizing the plasma membrane. It prevents vacuolar fusion by the definite interaction with ergosterol so, it is active against fungi but not against bacteria (Te Welscher et al., 2010).

\section{CONCLUSION}

The low-salt soft cheese has short shelf life due to the presence of aerobic spore-forming bacteria which are resistant to pasteurization temperature, therefore, the producers may use some chemical preservatives. From the above mentioned results and discussion, it could be concluded that some natural antibacterial agents could be used to inhibit the growth of aerobic spore-forming bacteria, which among them addition of lysozyme $(100 \mathrm{mg} / \mathrm{kg})$ in combination with nisin $(25 \mathrm{mg} / \mathrm{kg})$ had a great inhibitory effect on aerobic spore-forming bacteria followed by application of lysozyme alone.

\section{DECLARATIONS}

\section{Acknowledgements}

Great thanks are extended to Prof Dr Ashraf M. Nazem, Department of Food Hygiene, Faculty of Veterinary medicine, Alexandria University, Egypt and Prof Dr Sameh A. Awad, Department of Dairy Science and Technology, Faculty of Agriculture, Alexandria University, Egypt.

\section{Competing interests}

The authors declare that they have no competing interests.

\section{Consent to publish}

All authors agree on article publication.

\section{REFERENCES}

Abdou AM, Higashiguchi S, Aboueleinin AM, Kim M, and Ibrahim HR (2007). Antimicrobial peptides derived from hen egg lysozyme with inhibitory effect against Bacillus species. Food Control, 18(2): 173-178. DOI: http://www.dx.doi.org/10.1016/j.foodcont.2005.09.010

Abdou AM, Kim M, and Sato K (2013). Functional proteins and peptides of hen's egg origin. Bioactive food peptides in health and disease, pp.115144. Available at: https://www.intechopen.com/books/bioactive-food-peptides-in-health-and-disease/functional-proteins-and-peptides-of-hen-segg-origin

Al-Gamal MS, Ibrahim GA, Sharaf OM, Radwan AA, Dabiza NM, Youssef AM, and El-ssayad MF (2019). The protective potential of selected lactic acid bacteria against the most common contaminants in various types of cheese in Egypt. Heliyon, 5(3): e01362. Available at: https://www.sciencedirect.com/science/article/pii/S240584401838589X

Arabski M, Konieczna I, Tusińska E, Wąsik S, Relich I, Zając K, and Kaca W (2015). The use of lysozyme modified with fluorescein for the detection $\begin{array}{lllll}\text { of } \quad \text { Gram-positive } & \text { bacteria. Microbiological } & \text { research, 170: } & \text { 242-247. }\end{array}$ https://www.sciencedirect.com/science/article/pii/S0944501314000640

Arioli S, Scala GD, Remagni MC, Stuknyte M, Colombo S, Guglielmetti S, Noni ID, Ragg E, and Mora D (2016). Streptococcus thermophilus urease activity boosts Lactobacillus delbrueckii subsp. bulgaricus homo lactic fermentation. International journal of food microbiology, 247 : 55-64. DOI: http://www.dx.doi.org/10.1016/j.ijfoodmicro.2016.01.006

Ávila M, Gómez-Torres N, Hernández M, and Garde S (2014). Inhibitory activity of reuterin, nisin, lysozyme and nitrite against vegetative cells and spores of dairy-related Clostridium species. International journal of food microbiology, 172: 70-75. DOI: http://www.doi.org/10.1016/j.ijfoodmicro.2013.12.002

Awad RA, Farahat AM, and Salama WM (2012). Production and in vivo Nutritional Evaluation of Functional Soft Cheese Supplemented with Broccoli. World Journal of Dairy and Food Sciences, 7(2): 150-159. Available at: https://www.semanticscholar.org/paper/Production-and-invivo-nutritional-evaluation-of-Awad-Farahat/5ebd51f4bfa4626a3076436b29a6b585cb1ce276

Bae I, Park JH, Choi HY, and Jung HK (2017). Emerging innovations to reduce the salt content in cheese; effects of salt on flavor, texture, and shelf life of cheese; and current salt usage: A review. Korean journal for food science of animal resources, 37(6): 793-798. Available at: https://www.ncbi.nlm.nih.gov/pmc/articles/PMC5932950/

Beresford T, Fitzsimons N, Cogan T, and Condon S (1998). Non-starter lactic acid bacteria: Growth in cheese, contribution to flavor development. In Proceedings of the International Dairy Symposium, 19: 98-134. Available at: https://hal.archives-ouvertes.fr/hal-00895622/document

Budka H, Buncic S, and Colin P (2005). Opinion of the scientific panel on biological hazards on Bacillus cereus and other Bacillus spp. in foodstuffs. European Food Safety Authority Journal, 175: 1-48. Available at: https://efsa.onlinelibrary.wiley.com/doi/pdf/10.2903/j.efsa.2005.175

Chung W, and Hancock RE (2000). Action of lysozyme and nisin mixtures against lactic acid bacteria. International journal of food microbiology, 60(1): 25-32. Available at: http://www.cmdr.ubc.ca/bobh/wp-content/uploads/2016/10/214.-Chung-2000.pdf 
Clinical, and Laboratory Standards Institute (CLSI) (2018). Performance Standards for Antimicrobial Susceptibility Testing. 28th ed. Clinical and Laboratory Standards Institute (CLSI). Pp.100-121. Available at: http://file.qums.ac.ir/repository/mmrc/CLSI-2018-M100-S28.pdf

Coman MM, Verdenelli MC, Cecchini C, Silvi S, Orpianesi C, Boyko N, and Cresci A (2014). In vitro evaluation of antimicrobial activity of L actobacillus rhamnosus IMC 501®, L actobacillus paracasei IMC 502® and SYNBIO ${ }^{\circledR}$ against pathogens. Journal of applied microbiology, 117(2): 518-527. Available at: https://sfamjournals.onlinelibrary.wiley.com/doi/pdf/10.1111/jam.12544

Coorevits A, De Jonghe V, Vandroemme J, Van Landschoot A, Heyndrickx M, and De Vos P (2010). How can the type of dairy farming influence the bacterial flora in milk?.In Organic farming and peanut crops, pp. 123-136. Available at: http://www.hdl.handle.net/1854/LU-949761

Coorevits A, De Jonghe V, Vandroemme J, Reekmans R, Heyrman J, Messens W, De Vos P, and Heyndrickx M (2008). Comparative analysis of the diversity of aerobic spore-forming bacteria in raw milk from organic and conventional dairy farms. Systematic and Applied Microbiology, 31(2): 126-140. Available at: https://www.jmbfs.org/wp-content/uploads/2013/03/jmbfs_0290 gonzales.pdf

Doosh KS, and Abdul-Rahman SM (2014). Effect of Lysozyme Isolated from Hen Egg White in Elongation the Shelf Life of Iraqi Soft Cheese Made from Buffalo Milk. Pakistan Journal of Nutrition, 13(11): 635-641. DOI: http://www.doi.org/10.3923/pjn.2014.635.641

Egan K, Field D, Rea MC, Ross RP, Hill C, and Cotter PD (2016). Bacteriocins: novel solutions to age old spore-related problems?. Frontiers in microbiology, 7: 461. Available at: https://www.frontiersin.org/articles/10.3389/fmicb.2016.00461/full

Elsamani MO, Habbani SS, Babiker EE, and Ahmed IA (2014). Biochemical, microbial and sensory evaluation of white soft cheese made from cow and lupin milk. LWT-Food Science and Technology, 59(1): 553-559. Available at: http://khartoumspace.uofk.edu/bitstream/handle/123456789/22216/Pages\%20from\%20Biochemical,\%20microbial\%20and\%20sensory\%20evalu ation $\% 20$ of $\% 20$ white $\% 20$ soft $\% 20$ cheese.pdf?sequence $=1$

Fahmi AH, and Sharara HA (1950). Studies on Egyptian Domiati cheese. Journal of Dairy Research, 17(3): 312-328. DOI: https://www.doi.org/10.1017/S0022029900005860

Faille C, Benezech T, Midelet-Bourdin G, Lequette Y, Clarisse M, Ronse G, and Slomianny C (2014). Sporulation of Bacillus spp. within biofilms: a potential source of contamination in food processing environments. Food microbiology, 40: 64-74. Available at: http://ssu.ac.ir/cms/fileadmin/user_upload/Mtahghighat/tfood/asil-article/q-z2/Sporulation-of-Bacillus-spp-within-biofilms-A-potential-source-ofcontamination-in-food-processing-environments 2014_Food-Microbiology.pdf

Fox PF, Guinee TP, Cogan TM, and McSweeney PL (2017). Fundamentals of cheese science, pp. 185-229. Available at: https://www.springer.com/gp/book/9781489976796

Gharsallaoui A, Oulahal N, Joly C, and Degraeve P (2016). Nisin as a Food Preservative:Part 1: Physicochemical Properties, Antimicrobial Activity, and Main Uses, Critical Reviews in Food Science and Nutrition, 56 (8): 1262-1274. DOI: https://www.doi.org/10.1080/10408398.2013.763765

Gut IM, Blanke SR, and Van der Donk WA (2011). Mechanism of inhibition of Bacillus anthracis spore outgrowth by the lantibiotic nisin. ACS chemical biology, 6(7): 744-752. Available at: https://pubs.acs.org/doi/pdfplus/10.1021/cb1004178

Hawaz E (2014). Isolation and identification of probiotic lactic acid bacteria from curd and in vitro evaluation of its growth inhibition activities against pathogenic bacteria. African Journal of Microbiology Research, 8(13): 1419-1425. Available at: https://academicjournals.org/journal/AJMR/article-full-text-pdf/D80ED0B46925.pdf

Heyndrickx M (2011). The importance of endospore-forming bacteria originating from soil for contamination of industrial food processing. Applied and Environmental Soil Science, pp.1-11. Available at: https://www.hindawi.com/journals/aess/2011/561975/abs/

Komitopoulou E, Boziaris IS, Davies EA, Delves-Broughton J, and Adams MR (1999). Alicyclobacillus acidoterrestris in fruit juices and its control by nisin. International journal of food science and technology, 34(1): 81-85. DOI: https://www.doi.org/10.1046/j.1365-2621.1999.00243.x

Kumari S, and Sarkar PK (2016). Bacillus cereus hazard and control in industrial dairy processing environment. Food Control, 69: 20-29. DOI: https://www.doi.org/10.1016/j.foodcont.2016.04.012

Ibrahim A, and Awad S (2018). Selection and identification of protective culture for controlling Staphylococcus aureus in fresh Domiati like cheese. Journal of food safety, pp.1-7. DOI: https://www.doi.org/10.1111/jfs.12418

Lopes NA, Pinilla CMB, and Brandelli A (2019). Antimicrobial activity of lysozyme-nisin co-encapsulated in liposomes coated with polysaccharides. Food Hydrocolloids, 93: 1-9. DOI: http://www.doi.org/10.1016/j.foodhyd.2019.02.009

Lopez-Brea SG, Gomez-Torres N, and Arribas MA (2018). Spore-forming bacteria in dairy products. Microbiology in Dairy Processing: Challenges and Opportunities, First Edition Edited by Palmiro Poltronieri. () 2018 John Wiley and Sons Ltd and the Institute of Food Technologists Published 2018 by John Wiley and Sons Ltd and the Institute of Food Technologists,pp.11-32. Available at: http://ndl.ethernet.edu.et/bitstream/123456789/36457/1/37.pdf.pdf\#page=33

López-Pedemonte TJ, Roig-Sagués AX, Trujillo AJ, Capellas M, and Guamis B (2003). Inactivation of spores of Bacillus cereus in cheese by high hydrostatic pressure with the addition of nisin or lysozyme. Journal of Dairy Science, 86(10): 3075-3081. Available at: https://www.sciencedirect.com/science/article/pii/S0022030203739071

Meruvu H, Vangalapati M, Chippada SC, and Bammidi SR (2011). Synthesis and characterization of zinc oxide nanoparticles and its antimicrobial activity against Bacillus subtilis and Escherichia coli. Journal of Rasayan Chemistry, 4(1): 217-222. Available at: https://translateyar.ir/wpcontent/uploads/2018/12/8726-English.pdf

Morsy MK, Elsabagh R, and Trinetta V (2018). Evaluation of novel synergistic antimicrobial activity of nisin, lysozyme, EDTA nanoparticles, and/or $\mathrm{ZnO}$ nanoparticles to control foodborne pathogens on minced beef. Food Control, 92: 249-254. Available at: https://webcache.googleusercontent.com/search?q=cache:abw5tjc8HvQJ:https://pubag.nal.usda.gov/catalog/5974877+\&cd=1\&hl=en\&ct=clnk\&g $\underline{\underline{l}=\mathrm{eg}}$

Omardien S, Brul S, and Zaat SA (2016). Antimicrobial activity of cationic antimicrobial peptides against gram-positives: current progress made in understanding the mode of action and the response of bacteria. Frontiers in cell and developmental biology, 4: 111. Available at: https://www.frontiersin.org/articles/10.3389/fcell.2016.00111/full

Pirttijärvi TSM, Wahlström G, Rainey FA, Saris PEJ, and Salkinoja-Salonen MS (2001). Inhibition of bacilli in industrial starches by nisin. Journal of Industrial Microbiology and Biotechnology, 26(3): 107-114. Available at: https://link.springer.com/content/pdf/10.1038\%252Fsj.jim.7000078.pdf

Ramanauskiene K, Inkeniene AM, Savickas A, Masteikova R, and Brusokas V (2009). Analysis of the antimicrobial activity of propolis and lysozyme in semisolid emulsion systems. Acta Poloniae Pharmaceutica, 66(6): 681-688. Available at: https://pubmed.ncbi.nlm.nih.gov/20050532/

Rodriguez-Lozano A, Campagnoli M, Jewel K, Monadjemi F, and Gaze JE (2010). Bacillus spp. thermal resistance and validation in soups. Current Research, Technology and Education Topics in Applied Microbiology and Microbial Biotechnology, 1: 537-544. Available at: http://www.innocua.net/web/download-626/537-544.pdf

Silva CC, Silva SP, and Ribeiro SC (2018). Application of bacteriocins and protective cultures in dairy food preservation. Frontiers in microbiology, 9 : 594. Available at: https://www.frontiersin.org/articles/10.3389/fmicb.2018.00594/full 
Sobrino-López A, and Martín-Belloso O (2008). Use of nisin and other bacteriocins for preservation of dairy products. International Dairy Journal, 18(4): 329-343. DOI: http://www.doi.org/10.1016/j.idairyj.2007.11.009

Steel RG, and Torrie JH (1980). Principles and procedures of statistics 2nd ed. McGraw Hill, New York, USA, pp.1-633. DOI:

https://www.doi.org/10.1002/bimj.19620040313

Sudagidan M, and Yemenicioğlu A (2012). Effects of nisin and lysozyme on growth inhibition and biofilm formation capacity of Staphylococcus aureus strains isolated from raw milk and cheese samples. Journal of food protection, 75(9): 1627-1633. Available at: http://openaccess.iyte.edu.tr:8080/xmlui/bitstream/handle/11147/5630/56230pdf?sequence=1

Tharmaraj N, and Shah NP (2009). Antimicrobial effects of probiotics against selected pathogenic and spoilage bacteria in cheese-based dips. International Food Research Journal, 16(1): 261-276. Available at: http://www.ifrj.upm.edu.my/16\%20(3)\%202009/1[1]\%20Shah.pdf

Te Welscher YM, Jones L, Van Leeuwen MR, Dijksterhuis J, De Kruijff B, Eitzen G, and Breukink E (2010). Natamycin inhibits vacuole fusion at the priming phase via a specific interaction with ergosterol. Antimicrobial agents and chemotherapy, 54(6): 2618-2625 Available at: https://scholar.google.com/scholar?output=instlink\&q=info:SK8KVXIH3WcJ:scholar.google.com/\&hl=en\&as_sdt=0,5\&scillfp=1091424720486 5706296\&oi=lle

Wehr HM, and Frank JF (2012). Standard methods for the examination of dairy products (327-404). Washington, DC: American Public Health Association. DOI: http://doi.org/10.2105/9780875530024

Zottola EA, Yezzi TL, Ajao DB, and Roberts RF (1994). Utilization of cheddar cheese containing nisin as an antimicrobial agent in other foods. International journal of food microbiology, 24(1-2): 227-238. DOI: https://doi.org/10.1016/0168-1605(94)90121-X 